\title{
A PATCHWORK THEORY OF BLACKMAIL
}

\section{SCOTT ALTMAN†}

Blackmail poses many puzzles. Several legal divergences need justification. Demanding payment not to disclose embarrassing information is usually a crime, ${ }^{1}$ yet it is lawful to disclose such information and to demand payments for other forbearances. Parallel puzzles concern a moral divergence. Demanding payment not to disclose embarrassing information is a serious prima facie moral wrong, yet disclosing the information is often acceptable or only moderately immoral. ${ }^{2}$ Further, some people want justifications that account for the widely held intuition that blackmail wrongs its victim, not just society or particular third parties.

Justifying the moral and legal divergences implicates other controversies. We do not agree on what constitutes immorality, or about what justifies criminal sanctions. Thoroughgoing utilitarians write about whether permitting blackmail would reduce misallocation of resources. From their perspective, answering this question might resolve the legal and moral puzzles. But from many perspectives this question seems marginal. Inefficiency is grounds neither for condemnation nor for punishment. Nonetheless, everyone can benefit from dialogue. That people who disagree about many legal and moral questions usually favor punishing blackmailers suggests room for overlapping consensus on this issue.

† Associate Professor of Law, University of Southern California Law Center. For helpful comments, I thank Dick Craswell, Sidney DeLong, Tom Griffith, Marty Levine, Elyn Saks, Mike Shapiro, Larry Solum, and Matt Spitzer.

1 For a review of the variations in blackmail laws, see James Lindgren, Unraveling the Paradox of Blackmail, 84 Colum. L. REv. 670, 673-76 (1984). Among those primarily concerned with blackmail's legal status, some are interested in whether certain demands for payment in exchange for silence should be crimes, such as market-price blackmail, see Jeffrie G. Murphy, Blackmail: A Preliminary Inquiry, 63 MONIST 156, 163-65 (1980), blackmail of criminals, see Jennifer G. Brown, Blackmail as Private Justice, 141 U. PA. L. REv. 1935, 1943-49 (1993), or claim-of-right blackmail, see Lindgren, supra, at 677-80. Interest in these defenses seems partly driven by the belief that attitudes toward these defenses might provide hints about blackmail generally.

2 The question is sometimes stated more broadly: Why is it ever wrong to place a condition on doing a permissible but optional act? See Scott Altman, Divorcing Threats and Offers (Sept. 1992) (unpublished manuscript, on file with author). I limit this paper to the narrower category because some reasons for condemning and prohibiting blackmail are specific to problems of secrecy and information. 
We might more easily solve the legal and moral puzzles if we stop insisting that one principle must explain every aspect of blackmail. I recommend abandoning the search for a unified explanation. Probably no single flaw justifies condemning and prohibiting all and only blackmail transactions. Often multiple overlapping justifications support legal and moral obligations. Because blackmail is varied, different reasons might support condemning and prohibiting different forms. ${ }^{3}$ The legal ban (like most rules) is probably both overinclusive and underinclusive compared to the moral arguments supporting it. ${ }^{4}$

In this article, I present a patchwork of theories to justify condemning and prohibiting blackmail. Part I argues that most blackmailers commit two serious moral wrongs-coercion and exploitation-that justify condemnation and prohibition. Part II considers the sufficiency and necessity of explanations based on coercion and exploitation. I reach two conclusions. First, even though some blackmailers do not coerce or exploit, we rightly prohibit blackmail because the remaining blackmailers either commit some other serious wrong or are too rare and difficult to identify for practical exceptions. Second, a patchwork of theories best justifies our treatment of blackmail if it includes accounts of coercion and exploitation. Finally, Part III explains why we should not prohibit forms of hard bargaining that seem similar to blackmail. Many do not actually involve coercion and exploitation. Others can be deterred only with unacceptable costs not present in the case of blackmail.

\section{BLACKMAIL AS COERGion AND EXPLOITATION}

Two aspects of blackmail strike me as central to its immorality. First, many blackmailers would not have revealed the victim's secret had they lacked an opportunity to demand payment. Most blackmail differs in this regard from typical business transactions. Blackmailers sell secrecy, a product many of them would give away if unable to bargain. Grocers would not give away food if they could not demand payment. Both grocer and customer benefit

${ }^{3}$ The circumstances of blackmail vary in several ways, including the nature of the information, see Joel Feinberg, The Paradox of Blackmail, 1 RATTO JURIS 83 (1988), and the means and purpose of acquiring the information, see MIKE HEPWORTH, BLACKMAIL 29-40 (1975).

${ }^{4}$ See Frederick Schauer, Playing by the RUles 32 (1991). 
from the opportunity to bargain. On the other hand, the possibility of blackmail transactions primarily benefits blackmailers. ${ }^{5}$

Second, blackmailers profit from vulnerability. Blackmail succeeds when the victim believes exposure will create serious hardships: loss of dignity, reputation, safety, freedom, career, personal relationships, and other similarly central aspects of the individual's life. Blackmailers receive significant premiums over other potential uses for their information because blackmail victims want to avoid these harms.

In the remainder of this section, I explain why demanding payment for things one would otherwise have given away and profiting from vulnerability are sometimes serious moral wrongs to a victim.

\section{A. Coercion}

Without the opportunity to negotiate, many blackmailers would not reveal the information. Although some blackmailers could sell their information elsewhere, they could rarely do so as profitably. As a result, information acquired for the purpose of blackmail often would not have been acquired. ${ }^{6}$ Professional blackmailers might turn to kidnapping rather than journalism. Additionally, information acquired accidentally often would not have been disclosed. ${ }^{7}$ I will argue that most blackmail proposals are therefore threats, which commit the prima facie moral wrong of coercion. I first explain what I mean by a threat, and then why I think coercion is a prima facie wrong.

5 This point has been widely noted. See, e.g., George Daly \& J. Fred Giertz, Externalities, Extortion, and Efficiency: Reply, 68 AM. ECON. REV. 736, 736 n.2 (1978) (noting that while blackmailers do not directly benefit from revealing information, they nevertheless obtain compensation from the victim).

${ }^{6}$ This includes commercial research blackmail, in which information is intentionally acquired for the purpose of blackmail, and entrepreneurial blackmail, in which victims are enticed into compromising positions so that they can be blackmailed. See HEPWORTH, supra note 3, at 74-76.

7 This includes opportunistic blackmail in which information is discovered by accident, and participant blackmail, in which the information arises from some relationship between blackmailer and victim. See id. at 75-77. Although disclosure is often relatively easy, it is rarely costless. One must first locate an appropriate listener. The information will sometimes be unwelcome, making disclosure itself unpleasant. With some information one risks the social stigma of being labeled a gossip. 
Threats deprive the recipient of an important option available in some alternative situation. Writers disagree on how to describe the alternative situation. Possibilities include:

1. What is the statistically likely outcome for a person in this position $?^{8}$ (statistical baseline)

2. What outcome is the recipient morally or legally entitled to? (moral baseline)

3. What outcome did the recipient expect? ${ }^{10}$ (phenomenological baseline)

Tests using these baselines do not detect all wrongful proposals. I have argued elsewhere that the moral baseline must be supplemented with a nonmoral baseline $e^{11}$ and that the statistical and phenomenological baselines fail to identify coercion. ${ }^{12}$ I suggest a baseline that inquires into a specific counterfactual question: If the proposer could not have imposed the condition, would the proposer have given the benefit or withheld the harm anyway? ${ }^{13}$ If the answer is yes, and if the option was important to the recipient, then the proposer removes otherwise available important options. ${ }^{14}$ The removal of important available options to alter someone's actions is coercion.

Other baselines neglect available-option removal. What usually happens, what the recipient thought would happen, or what should happen does not indicate whether a proposal actually removed an available option. Whether an option was available depends on what would have happened in this case without the proposal.

8 Nozick refers to the "normal or usual course of events." Robert Nozick, Coercion, in PHILOSOPHY, Politics, AND Society 101, 116 (Peter Laslett et al. eds., 1972).

${ }^{9}$ See, e.g., Charles Fried, Contract as Promise 97-99 (1981) (defining whether an act is coercive "in terms of the rights of the parties"); Cheyney C. Ryan, The Normative Concept of Coercion, 89 MIND 481, 483-91 (1980) (exploring how a consideration of rights informs the definition of coercion).

${ }^{10}$ See ALAN WERTHEIMER, COERCION 207 (1987).

11 Many blackmailers coerce even on a moral baseline because they propose to reveal information they are obligated not to reveal.

12 See Altman, supra note 2, at 3.

${ }^{13}$ See id. This baseline is close to the category Nozick identifies as unproductive exchanges. See Robert NOZICK, ANARGHy, STATE, AND UTOPIA 85 (1974). My account differs from his in several respects. First, I believe these proposals are threats, morally wrongful for limiting freedom. Nozick adopts an account of threats that relies on a combined statistical and moral baseline. See Nozick, supra note 8, at 116. Second, I explain why these proposals are immoral. Third, I identify exploitation as a central moral flaw in most of these exchanges.

14 See Altman, supra note 2, at 4. 
Consider, for example, a drowning victim. The only available potential rescuer proposes to save the victim for a promise of cash. Whether this proposal has removed the option of being saved for free depends on what this potential rescuer would have done if demanding payment were impossible. If this person would have attempted the rescue, then the proposal removed the otherwise available option of being saved without promising cash. If this person would have left the victim, then the opportunity to negotiate made available the chance to be saved. ${ }^{15}$

Removing otherwise available important options can be condemned as prima facie wrong based on a variety of moral views. I have elsewhere argued that it violates norms of respecting autonomy and not treating others as only means. ${ }^{16}$ A contractarian argument supports the same conclusion. Any person should accept and would benefit from a presumption against such proposals. If each of us took every opportunity we have to threaten others everyone would be worse off, including even those who sometimes benefit by making threats. At every moment someone would be demanding payment not to make noise or to do some act for which we all depend on others each day. To avoid the constant stream of threats, everyone would invest in wasteful precautionary devices to insulate themselves from vulnerability. The time and expense of many otherwise unnecessary negotiations would also make everyone poorer.

A presumption against such threats has few costs. A norm against asking to be paid for what one is willing to do for free does not prevent beneficial bargains because it never disallows anyone from receiving a minimum asking price. Because a general rule against threats benefits everyone at little social cost, it should be regarded as a prima facie moral rule no less than rules against theft and physical violence.

I5 Sometimes the ability to negotiate affects other facets of the negotiation. Without the chance to negotiate, the proposer might not be present at all. See, e.g., William M. Landes \& Richard A. Posner, Salvors, Finders, Good Samaritans, and Other Rescuers: An Economic Study of Law and Altruism, 7 J. LEGAL STUD. 83, 99 (1978) (stating that the quantity of "rescue inputs" will rise as compensation is introduced). In these cases, whether a proposal has increased freedom depends on whether the ability to negotiate in similar cases increased the options available to this person.

${ }^{16}$ See Altman, supra note 2, at 4, 15-16. 


\section{B. Exploitation}

Blackmail victims are particularly vulnerable. They can be driven to irrational ${ }^{17}$ or criminal behavior. ${ }^{18}$ Although this vulnerability has been widely noted, it has not satisfactorily solved puzzles about blackmail. Irrational bargains are not usually crimes, and the potential to create subsidiary crime does not explain why blackmail wrongs its victims. I will argue that blackmailers profit from their victims' vulnerability in specific ways that constitute prima facie wrongful exploitation.

To avoid controversial positions I define exploitation narrowly as "benefitting at another person's expense from her difficulties." 19 By "benefitting at another person's expense," I mean obtaining a better deal in negotiation than one would have obtained for the same good or service had that person lacked the difficulty. ${ }^{20}$ By "difficulty" I mean more than just strong desire for some service or product. I mean something closer to loss of, or choice between, primary goods. ${ }^{21}$ For example, charging higher than face value for scarce tickets to a sporting event does not exploit the buyer because there is no reason to think the buyer's desire to attend stems from any hardship. On the other hand, charging poison victims who face imminent death more for medication than

17 David Owens suggests blackmail victims are irrational because blackmailers cannot deliver secrecy. See David Owens, Should Blackmail be Banned?, 63 PHIL. 501,507 (1988). Owens overstates blackmail victims' inability to estimate the likelihood of alternate sources of disclosure. See Hugh Evans, Why Blackmail Should be Banned, 65 PHIL. 89, 90 (1990). Owens, however, understates the real irrationality of victims-believing that blackmailers will not later demand more payment. See HEPWORTH, supra note 3 , at 42 (stating that recurring demands for money are a frequent feature in recorded cases).

18 See Richard A. Epstein, Blackmail, Inc., 50 U. CHI. L. REv. 553, 564 (1983).

${ }^{19} \mathrm{~A}$ broader definition would include benefits not obtained at the expense of a victim, and would expand the characteristics that one should not benefit from to include admirable qualities. See Joel Feinberg, Noncoercive Exploitation, in PATERNALISM 201, 203 (Rolf Sartorius ed., 1983) (defining exploitation to include making a profit or gain from another's strength or virtue as well as weakness or flaw).

${ }^{20}$ See Deirdre Golash, Exploitation and Coercion, $15 \mathrm{~J}$. VALUe INQUIRY 319, 324 (1981); Anthony T. Kronman, Contract Law and Distributive Justice, 89 YALE L.J. 472,478 (1980).

${ }^{21}$ See JOHN RAWLS, A THEORY OF JUSTICE 62 (1971) (listing primary goods to include rights, liberty, power, opportunities, income, wealth, self-respect, health, vigor, intelligence, and imagination). 
one would charge less desperate purchasers of the same drug exploits their hardship. ${ }^{22}$

Blackmailers typically exploit their victims' vulnerability in several ways. First, they demand more for silence than the price for which they could have sold the information. This differs from most decisions to sell a product to the highest bidder because the power to price silence higher than disclosure (even if the market for the information is competitive) derives from the victim's desire to avoid serious hardship. Second, blackmailers frequently demand repeated payments for their silence. ${ }^{23}$ Victims often regard prior payments as sunk costs and do not complain about the blackmailer's breached promise to keep silent for fear of disclosure. In both respects blackmailers benefit-increase their profits-from their victims' hardship.

Exploitation is prima facie wrong because it contributes to various forms of injustice. Blackmailers' exploitation usually contributes to injustice by compounding hardship. This is sometimes called "justice according to Saint Matthew."24 Poor people spend more for food than rich people. Homeless persons who have nowhere to sleep are arrested in public places for loitering or illegal camping. Exploiters who benefit at the expense of people in hard circumstances take part in this form of injustice.

\section{PATChING TheORIES TOgETHER}

Recognizing that many blackmailers both coerce and exploit accounts for several difficulties. Coercion and exploitation wrong a victim. These wrongs deserve significant blame, especially when they occur together. Acts that both coerce and exploit are rarely justifiable because the main justifications for coercion-paternalism and preventing the wrongful act of another-are rarely present when the purpose of coercing is to create exploitable hardship. Exploitation is thus both a wrong itself and a fact that precludes justification for coercion. ${ }^{25}$

22 See Altman, supra note 2, at 10.

23 See HEPWORTH, supra note 3, at 42.

24 See JON ELSTER, SOLOMONIC JUDGMENTS: STUdIES IN THE LIMITATIONS OF RATIONALITY 140 (1989); see also Matthew 25:29 (New English) ("For the man who has will always be given more, till he has enough and to spare; and the man who has not will forfeit even what he has.").

${ }^{25}$ See Altman, supra note 2, at 18-19. David Zimmerman discusses a person who kidnaps a victim to an island for the purpose of employing the victim at a very low wage. See David Zimmerman, Coercive Wage Offers, 10 PHIL. \& PUB. AFF. 
This account suggests why blackmail is often worse than revealing embarrassing information. Revealing embarrassing information, though it alters options, does not usually coerce. It does not coerce because the purpose of revelation is not usually to induce the person to do anything. Limiting another's options in order to alter her behavior is prima facie wrong for reasons that do not apply to altering her options for other purposes. ${ }^{26}$ Everyone benefits from and can abide by a rule against threats. But we cannot avoid limiting one another's options when we act for other purposes.

Revealing information does not usually exploit. Unlike most blackmailers, many people who reveal embarrassing information do so for nonexploitative purposes: to aid police in capturing criminals, to inform the public of important news, or to collect a reward. Revelation does not exploit unless profits increase based on characteristics such as hardship.

Despite these advantages, theories of coercion and exploitation do not solve the longstanding problems of blackmail. First, these ideas alone cannot explain the immorality of blackmail. A patchwork is needed to explain all that is wrong with blackmail, and what is wrong with all blackmail. Second, these are controversial theories. Perhaps a patchwork of explanations that rejects such controversies is preferable. I address these two concerns in turn and conclude that theories of coercion and exploitation are necessary but not sufficient to explain blackmail.

\section{A. Noncoercive Blackmail}

Not all blackmail fits the paradigm of coercion I describe. If unable to negotiate, some blackmailers would acquire information in order to reveal it. Some would disclose information accidentally acquired. Must I admit that these blackmailers do no wrong or that we should decriminalize their behavior? I do not think so. Most of these blackmailers either commit some other wrong, or cannot be identified easily enough to create a practical exception to the blackmail laws. If those who commit no wrong are rare and difficult

121,133 (1981). Although blackmailers do not commit acts of violence, insofar as they limit freedom in order to take advantage of the limits created, blackmailers and Zimmerman's kidnapper share an important characteristic.

${ }^{26}$ This distinction is common. See, e.g., Kent Greenawalt, Criminal Coercion and Freedom of Speech, 78 Nw. U. L. REv. 1081, 1098 (1983) (defining manipulative threats as those that are both "situation-altering" and "action-inducing"). 
to detect, we rightly ban blackmail except for narrowly stated exceptions.

Many blackmailers propose to reveal information that is immoral or illegal to reveal, such as appropriately private information, information acquired by invasions of privacy, or false information. ${ }^{27}$ Others propose to keep secret information they ought to disclose, such as information about commission of crimes. Still others propose to decide about disclosure based on grounds that they ought to ignore, such as the newspaper publisher who proposes to publish information if not paid. ${ }^{28}$ Although this case is thought to raise a puzzle, it seems to me a simple case of corruption. ${ }^{29}$ Most newspaper publishers have assumed an obligation to make publication decisions based on judgments about newsworthiness. ${ }^{30}$ Taking payment to quash stories is thus morally corrupt.

Most blackmailers exploit, demanding much more for silence than they could have received for disclosure. They are able to do so because their victims seek to protect central aspects of their lives.

What about market-price-only blackmailers who demand for silence only what they could and would have received for disclosure? ${ }^{31}$ This practice is less wrong than most blackmail. If the proposer does not exploit, or remove otherwise available important options, the transaction is likely no worse than actual disclosure. ${ }^{32}$ For example:

Susan, while trying out her new video camera, accidentally films Allan-a Hasidic Jew dressed in traditional garb-eating lunch at Porky's Porkchops. The local television station is holding a contest offering $\$ 100$ for embarrassing videos. Susan rightly

${ }^{27}$ See Feinberg, supra note 3, at 93 (discussing fabricated blackmail); Lindgren, supra note 1 , at 689 n.102 (same).

${ }^{28}$ See, e.g., Owens, supra note 17, at 501-03 (hypothesizing a scenario involving a newspaper editor who unearths compromising information about a cabinet minister).

${ }^{29}$ There is a puzzle about corruption cases. What accounts for our intuition that the victim of blackmail is a victim? If the duty was owed to the public, or another qualified applicant, one could understand punishing the blackmailer, but why should the person asked to pay have any moral complaint? I suspect that the answer lies in a combination of apprehensions that very often the victim is deprived of something, concerns about exploitation, and simple prophylactic intuitions.

${ }^{30}$ Not all publishers purport to make decisions on such a basis, but most news sources explicitly or implicitly assume such an obligation. The New York Times, for example, proclaims each day: "All the news that's fit to print."

${ }^{31}$ See Lindgren, supra note 1 , at 693.

32 See Murphy, supra note 1 , at 164-65. 
believes that her video can win. She demands $\$ 100$ of Allan for the only copy of the video.

In my view, Susan ought not disclose Allan's secret. I do not think it worse, however, to sell Allan the video than to reveal it. She is not exploiting because her price is not increased due to Allan's difficult circumstances. She does not expose Allan to the likelihood of future exploitation because she will give him the only copy of the video. If unable to negotiate with Allan she would enter the contest, so the proposal actually improves Allan's options.

Perhaps some blackmailers do nothing wrong. Susan might have videotaped Bob, a famous athlete, tripping. If disclosure would expose Bob to no harm beyond a few jokes, I see no moral objection to disclosing the film or selling it to Bob for $\$ 100$.

I nonetheless support a law prohibiting Susan's behavior in both cases for prophylactic reasons. The situation is probably rare, ${ }^{33}$ and difficult to distinguish from serious moral wrongs. Marketprice-only blackmail is hard to detect because there cannot be any guarantee that a first payment will not be followed by more demands. ${ }^{34}$ Even if blackmail were lawful, the practical problems of enforcing promises not to reveal embarrassing information would be overwhelming. ${ }^{35}$ Noncoercive blackmail is impossible to detect because there is no way to distinguish blackmailers who would have disclosed the information without the chance to negotiate from those who propose the transaction only in order to extract payment for their silence.

We rightly risk deterring the beneficial and acceptable transaction between Allan or Bob and Susan in order to protect many people from exploitation, coercion, and breached obligations, and

${ }^{33}$ One reason to think the situation with Bob is rare is that if someone will pay very much for nondisclosure, the information is likely damaging. If so, there is likely some obligation either not to disclose or to disclose it.

${ }^{34}$ Even Susan might later demand further payment not to tell people what she saw.

${ }^{35}$ See Epstein, supra note 18, at 563. Blackmail contracts are unlike other promises, even promises to keep trade secrets. First, a blackmail victim might not want the enforcing court to know the embarrassing secret. Second, injunctions do no good if the blackmailer divulges the information. In the case of a trade secret, the informed party can be enjoined from using the information. With blackmail, mere revelation is the harm. Third, contract remedies may be insufficient. Unlike trade secrets, the breach of which money can compensate, a blackmail victim likely prefers secrecy to reimbursement or other compensation. Because victims will ignore sunk costs in deciding whether to reject succeeding demands, victims can be induced over time to pay more for secrecy than it is worth to them. 
to deter evildoers from committing these acts. In those few cases in which we can identify blackmailers who do not coerce and exploit, or who do so with justification, the law tries to provide practical defenses and exceptions. ${ }^{36}$

For example, claim-of-right blackmail involves a threat to inform the public of an individual's failure to satisfy a debt unless the debt is paid. ${ }^{37}$ Permitting such blackmail might be justified because, if unable to demand satisfaction, the person often would inform the public anyway. Additionally, because the price asked is only what is owed, it is not exploitative. Finally, the enforcement of a goodfaith claim might justify some prima facie wrong.

Similarly, permitting payer-initiated bargains might reflect the intuition that payers would not offer to pay for silence unless they had reason to think the other party planned to reveal the information. ${ }^{38}$ If so, permitting such bargains roughly reflects the acceptability of noncoercive blackmail. The correlation, however, is only rough. ${ }^{39}$ Evidentiary and definitional problems with payer-initiation can undermine any power it has to separate coercive from noncoercive transactions. Some bargains appear payer-initiated because the payer initially suggests the deal. But the payer might only learn of the other party's intent to reveal the embarrassing information after that party discloses this intent in order to elicit an offer of payment. Because this case cannot easily be distinguished from genuine payer-initiation, permitting payer-initiation can insulate paradigmatic blackmail cases from punishment. ${ }^{40}$

Of course, I am speculating about the frequency and identifiability of different kinds of blackmail. These speculations might play an important role in decisions to prohibit blackmail or define its

${ }^{36}$ For a detailed discussion of what circumstances might justify or excuse blackmail, see JOEL FEINBERG, HARMLESS WRONGDOING 262-69 (1988).

37 See Lindgren, supra note 1 , at 677-79.

${ }^{38}$ For an extended argument that theories of blackmail must explain why victim-initiated transactions are lawful, see generally Sidney W. DeLong, Blackmailers, Bribe Takers, and the Second Paradox of Blackmail, 141 U. PA. L. REV. 1663, 166585 (1998).

${ }^{39}$ Payers will often be wrong in assuming that the other party would disclose if unable to negotiate. The exclusion is thus overinclusive. It is also underinclusive because some recipient-initiated transactions will involve individuals who would disclose if unable to bargain. In addition, there is little to prevent exploitation in payer-initiated bargains.

${ }^{10} \mathrm{~A}$ parallel problem arises distinguishing the crime of bribe-taking from extortion. Compare United States v. Aguon, 851 F.2d 1158 (9th Cir. 1988) (en banc) (extortion requires an act inducing the payment) with Evans v. United States, 112 S. Ct. 1881 (1992) (extortion does not require any inducement). 
scope. ${ }^{41}$ Like any limit on apparently consensual bargains, the criminalization of blackmail makes some potential blackmail victims worse off. They would prefer to pay the price of silence rather than suffer disclosure. But if relatively few people would acquire silence because of the market, then combatting the ills of coercion, exploitation, breached obligation, and consequential harms of blackmail $^{42}$ exacts a low social cost. Like any market intervention, 'its wisdom depends in part on the number of consumers benefitted compared to the number of consumers hurt as well as on the magnitude of the effects. ${ }^{43}$

Several observations made in this Symposium make me hesitate about the broad prohibition of blackmail. First, perhaps many blackmailers would disclose information if unable to negotiate, even if blackmail were legal. If blackmail laws actually do remove many opportunities, perhaps the ban on blackmail unwisely sacrifices the welfare of many willing purchasers to protect few real victims from coercion. Second, perhaps we could accurately distinguish coercive and noncoercive blackmail. For example, we might permit a defense to blackmail charges if the blackmailer had credible evidence that a third party would have paid for the information. Such evidence would suggest that the blackmailer would have disclosed if unable to negotiate. Perhaps this mechanism could also screen for exploitation. The defense might be limited to cases in which the blackmailer demanded no more for silence than the third party would have paid for the information. Additionally, we might permit the defense only in cases that the blackmailer somehow could not easily have demanded additional payments.

I can hardly insist that I am right about either the frequency of wrongful blackmail or the practicality of such defenses. I claim only that if my speculations are true, they justify prohibiting blackmail,

41 Michael Gorr notes that we cannot automatically assume that most blackmailers would keep silent if unable to negotiate; we simply do not know. See Michael Gorr, Liberalism and the Paradox of Blackmail, 21 PHIL. \& PUB. AFF. 43, 61 (1992). Although I agree that we do not know, our rules and moral intuitions might be based on an educated guess.

42 See infra notes 57-63 and accompanying text.

${ }^{43}$ See Richard Craswell, Passing on the Costs of Legal Rules: Efficiency and Distribution in Buyer-Seller Relationships, 43 STAN. L. REV. 361 (1991). Michael Gorr relies on a less consequentialist argument for a similar conclusion. In his view, those potential blackmail victims made worse off by the ban on blackmail are less entitled to concern than those benefitted because the former often are wrongfully keeping information secret. He has criminals primarily in mind. See Gorr, supra note 41 , at $62-63$. 
and that in the absence of better evidence we can do no more than hypothesize as best we can.

\section{B. A Less Controversial Patchwork}

I have so far suggested that blackmail is wrong for a variety of moral reasons, including that it is often coercive and exploitative. My accounts of coercion and exploitation are admittedly controversial. Even those who accept them as moral accounts might reject them as justifications for criminal penalties because they do not involve rights violations or because they justify prophylactic rules. ${ }^{44}$ Might a patchwork of explanations that does not rely on prophylactic arguments and on controversial notions of coercion and exploitation succeed? In this section, I consider a number of prominent theories, all of which explain important aspects of blackmail's immorality. I conclude that they fail as a group to explain some aspects of blackmail unless supplemented with accounts of coercion and exploitation, or extended in ways that make them at least as controversial as the explanation provided here.

These arguments are nonetheless valuable parts of a patchwork theory of blackmail. The sheer number of overlapping moral objections to blackmail explains both why people regard it as so immoral, and why those with such different moral commitments agree about its immorality. Furthermore, the variety of moral objections supports a patchwork justification for prohibition: although no single moral objection applies to all blackmail, almost no blackmail avoids moral condemnation on all grounds. Blackmail that does avoid all moral objections usually cannot be identified easily enough to support exceptions to blackmail laws.

44 Eric Mack considers the argument that blackmail is usually immoral and that we cannot easily isolate moral blackmail. Mack considers this a reason to permit blackmail. He apparently believes that only immoral acts that violate rights can be crimes. See Eric Mack, In Defense of Blackmail, 41 PHIL. STud. 273, 283 (1982); see also Walter Block, Trading Money for Silence, 8 U. HAW. L. REv. 57, 73 (1986) (arguing that blackmail, while not ethical, is not an "invasive act, nor threat thereof, not an initiation of violence, nor a violation of rights" and therefore should not be criminalized); Michael Gorr, Nozick's Argument Against Blackmail, 58 PERSONALIST 187, 190 (1977) (arguing that laws against blackmail cannot be upheld based upon the theory that blackmail is an "unproductive" economic transaction). 


\section{Rights and Duties}

One could try, like Joel Feinberg or Michael Gorr, to base the immorality of blackmail exclusively on the insight that many blackmailers propose to reveal information that they morally ought to disclose, morally ought to keep secret, or morally ought to decide whether to disclose based on grounds other than price. ${ }^{45}$

Relying on this argument as a complete answer poses problems. First, on many plausible views of moral obligation, revelation is sometimes permissible and nonmandatory. For example, many people believe that disclosing marital infidelity to a cheated spouse is sometimes permissible but not required. Yet demanding payment not to do so is a paradigm case of wrongful blackmail. ${ }^{46}$ In order to address this difficulty, moral-obligation solutions require a controversial commitment to the pervasiveness of obligations.

Second, even if all blackmailers had uncontroversial obligations to disclose, to keep silent, or to decide on other grounds, these obligations do not explain the entire wrong. Obligations to disclose are often owed to someone besides the blackmail victim. Yet most people believe that blackmail wrongs its victims, not just third parties. Further, blackmail is often far worse than inappropriate disclosure or nondisclosure. This suggests that some of the wrong stems from sources other than the breached obligation. ${ }^{47}$ Finally,

45 See Feinberg, supra note 3, at 83-84; Gorr, supra note 41, at 46 . One who adopts this position must believe either that no human behavior is morally optional or that no disclosure decision with consequences severe enough to make blackmail possible is morally optional.

${ }^{46}$ Feinberg admits that the adultery case is a problem, and concludes that blackmail of this sort should be lawful. See FEINBERG, supra note 36, at 249. Gorr argues that there is always either a duty to disclose marital infidelity or an obligation to keep it secret, though which cases are which is not always clear. See Gorr, supra note 41 , at $62-63$.

${ }^{47}$ Leo Katz provides an ingenious response to this difficulty. He claims that we should judge the morality of blackmail not by the importance of the obligation blackmailers threaten to breach, but by the severity of the action they take, receiving property. See Leo Katz, Blackmail and Other Forms of Arm-Twisting, $141 \mathrm{U}$. PA. L. REV. 1567, 1598 (1993).

I do not find this argument completely convincing. If Professor Katz were right, we should regard it as a serious moral wrong, perhaps appropriately criminalized, for a factory owner to demand payment for reducing pollution levels below legally mandated limits. Surely polluting (even lawfully) is often as immoral as disclosing secrets. Yet demanding payment for silence seems a greater moral wrong than demanding payment for cleaner air. In my view, this is so because the latter is likely not coercive. If unable to demand payment, the polluter would continue polluting. 
disclosure is often legally optional. This suggests that some moral obligations are too small or of the wrong sort to justify legal enforcement. If so, why should we attach legal consequences to conditional breach of these obligations? ${ }^{48}$

One might respond to these difficulties by adding Hugh Evans's suggestion that there is always some obligation, albeit defeasible, not to say embarrassing things. We do not prohibit embarrassing disclosures because concerns about free expression justify permitting the harm. Because blackmail proposals result in silence if accepted, free expression concerns weigh less heavily and do not justify permitting the harm. ${ }^{49}$

Evans's theory explains how all acts of blackmail breach obligations, why the blackmail victim is the beneficiary of these obligations, and why we punish blackmail but not disclosure. His account, however, does not explain why blackmail is often morally far worse than actual disclosure. Protecting free speech need not temper moral condemnation. Yet breaching obligations of secrecy by disclosing rarely seems as bad as breaching them through blackmail. This suggests that the wrong of blackmail does not stem solely from breaching obligations to keep silent. Further, the wrong Evans identifies does not seem serious enough to justify criminal penalties. Even when disclosure is considered bad enough to transgress legal limitations, such as slander or disclosure of private facts, it carries only civil penalties.

\section{Third-Party Interests}

One could supplement moral-obligation arguments with Jim Lindgren's suggestion that blackmailers inappropriately use the interests of third parties to gain leverage in a transaction. In those cases in which the information will be kept from someone involved in a dispute with the victim, the blackmailer, bargaining with someone else's chips, has settled the dispute and kept some of the proceeds for himself. ${ }^{50}$

${ }^{48}$ Larry Solum has suggested to me that this last problem might be solved by recognizing how hard it is in any given case to know whether one is obligated to disclose or not to disclose. For example, deciding whether to reveal a marital infidelity committed by one friend against another might be a difficult moral decision. Because reaching the right outcome will be subject to error, we should not criminalize a bad decision. But one can easily know that one should not decide on the basis of the unfaithful spouses' willingness to pay.

${ }^{49}$ See Evans, supra note 17, at 93.

${ }^{30}$ See Lindgren, supra note 1 , at 702 (noting that the leverage exerted by a 
This suggestion also has its limits. First, persons deprived of information often have no claim that is compromised by this lost information. Yet in such cases blackmailers commit serious wrongs by demanding payment for their silence. For example, if I tell you that I will inform your neighbors that your father was a war criminal unless you pay me a large sum, I have committed a serious wrong even though I have not used anyone else's rights or settled anyone else's dispute inappropriately. Second, what is immoral about using the rights of third parties and why is it not similarly wrong simply to remain silent? In both cases, failing to provide the information effectively settles the dispute. Third, it leaves unexplained the intuition that blackmailers wrong the threatened party. ${ }^{51}$

\section{Promoting Virtues}

Several writers have suggested that blackmail laws promote various virtues. These theories assume controversial moral views, especially when used to justify criminal sanctions. Further, they do not alone seem sufficient to justify the severity or expansiveness of blackmail laws. ${ }^{52}$ Nonetheless as part of a patchwork, each adds a good reason for condemning some blackmailers.

Jeremy Waldron suggests that blackmailers who demand payment to keep silent about evil acts are complicit with evil. ${ }^{53}$ Complicity arguments, however, are very controversial. Few people are willing to punish complicity that does not encourage or aid evildoers. ${ }^{54}$ Fewer still would punish complicity with evil acts that are

blackmailer "belongs more to a third person than to the blackmailer").

${ }^{51}$ During his presentation at the Blackmail Symposium, Professor Lindgren pointed out that he never intended his chip theory as a sufficient reason for criminalization, only a necessary one. He favors banning blackmail when it both coerces and wrongfully uses the chip of a third party. His chip analysis, he says, comprehends a form of exploitation. As part of such a patchwork, I find his arguments more compelling.

52 Wendy Gordon suggests that blackmail laws serve to promote the virtue of pride. See Wendy J. Gordon, Truth and Consequences: The Force of Blackmail's Central Case, 141 U. PA. L. REv. 1741, 1780-82 (1993). She does not fall into the trap of thinking this purpose alone justifies prohibiting blackmail. Rather, she offers this as a benefit of prohibition which she justifies based on a theory of coercion.

${ }^{53}$ See Jeremy Waldron, Blackmail as Complicity 4 (Nov. 1992) (unpublished manuscript, on file with author).

54 Waldron notes laws against profiting from crimes such as the Son of Sam law. See Waldron, supra note 53, at 17-18; cf. Simon \& Schuster, Inc. v. New York State Crime Victims Bd., 112 S. Ct. 501 (1991) (declaring unconstitutional New York's "Son of Sam" statute, which required that an accused or convicted crimi- 
themselves not subject to punishment. Complicity also does not explain the immorality of blackmailing those who fear revelation for reasons other than condemnation. For example, if I discover that a neighbor is a movie star living in secret to avoid the throngs of adoring fans who make her life difficult, it would be immoral and appropriately criminal to demand payment to forego telling the tabloids. Yet I have not evidenced any inappropriate attitude toward evil.

Complicity theories also do not explain why we regard blackmail victims as victims. Waldron acknowledges this and suggests we should not feel sorry for blackmail victims. Some supposed victims are vicious people who deserve to be exposed and punished..$^{55}$ I do not think this a reason to abandon the intuition that blackmailers wrong their victims. First, not all blackmail victims are vicious people deserving punishment. Second, people who deserve punishment are wronged if harmed by someone not entitled to carry out that punishment. The fact that wrongdoers do not deserve pity does not prevent condemning those who act badly toward them. For example, it is both illegal and prima facie immoral to steal from a thief. That we feel little sympathy for the victim does not prevent understanding theft as a wrong to the victim.

\section{Domination}

George Fletcher suggests that blackmail is immoral and appropriately prohibited because blackmail creates relationships of domination. Because the blackmailer can almost always repeat demands, the relationship is potentially infinite. ${ }^{56}$ Although I agree that creating such a relationship is immoral and appropriately criminalized, I do not think this a complete justification for condemning and prohibiting blackmail. First, the criminal nature of making repeated demands does not explain why the first demand should be criminal. If the explanation is that the latter is needed because one cannot detect the former, then the crime might be too prophylactic to satisfy some people. Second, even if we rightly

favors imprisoning publishers who sell books about crimes.

${ }^{55}$ See Waldron, supra note 53 , at 8-9.

56 See George P. Fletcher, Blackmail: The Paradigmatic Crime, 141 U. PA. L. REv. 1617,1626 (1993). Sidney DeLong's view that blackmail undermines community by isolating its victims relies in part on this same argument. See DeLong, supra note 38, at $1690-92$. 
prohibit the first demand to deter the second, this account does not explain moral condemnation of the first demand. Perhaps we condemn the first demand because it creates the danger of a future relationship of domination. But this explanation seems insufficient to account for the severity of condemnation. Finally, we condemn and prohibit blackmail even when future demands are unlikely or impossible.

\section{Waste and Subsidiary Harms}

One might explain the wrong of blackmail based on its bad consequences. Blackmail might encourage wasteful investigations and invasions of privacy; ${ }^{57}$ increase transaction costs and inefficien$\mathrm{cy}^{58}$ conceal fraud and other important information,;9 cause overenforcement or underenforcement of criminal laws; ${ }^{60}$ and encourage its victims to turn to crime to pay blackmailers. ${ }^{61}$

These insights alone do not resolve most people's concerns about blackmail. They do not account for the strong intuition that blackmail is a wrong to the victim. And for all but the most committed consequentialist, they fail to explain why blackmail is a very serious offense deserving criminal punishment. ${ }^{62}$ Nonetheless, in conjunction with the prophylactic arguments discussed above, they urge the selection of blackmail from among wrongful transactions as worth deterring. ${ }^{63}$

${ }^{57}$ See Joseph Isenbergh, Blackmail from A to C, 141 U. PA. L. REv. 1905, 1911-15 (1993); Murphy, supra note 1, at 158-59.

${ }^{58}$ See, e.g., Ronald H. Coase, The 1987 McCorkle Lecture: Blackmail, 74 VA. L. REv. 655, 673 (1988); Douglas H. Ginsburg \& Paul Shechtman, Blackmail: An Economic Analysis of the Law, 141 U. PA. L. REV. 1849, 1859-65 (1993); Steven Shavell, Economic Analysis of Threats and Their Illegality: Blackmail, Extortion, and Robbery, 141 U. PA. L. REV. 1877, 1899-1900 (1993).

${ }^{59}$ See Epstein, supra note 18, at 564; Isenbergh, supra note 57, at 1925-27.

${ }^{60}$ See William M. Landes \& Richard A. Posner, The Private Enforcement of Law, 4 J. Legal Stud. 1, 42 (1975); Richard A. Posner, Blackmail, Privacy, and Freedom of Contract, 141 U. PA. L. REv. 1817, 1821-23 (1993). But see Brown, supra note 1, at 1956-58 (arguing that concerns about overenforcement and underenforcement are based on faulty assumptions).

61 See Epstein, supra note 18, at 564.

${ }^{62}$ Divergence between those interested in blackmail's efficiency and those interested in its condemnation and criminalization can be seen in Ginsburg's analogy between the criminalization of blackmail and laws creating tort actions for spite fences. See Ginsburg, supra note 58, at 1860-65. Both promote efficiency, but their mechanism for doing so differs. Threatening to construct a spite fence or even erecting one is no crime. If the disclosure of embarrassing secrets really resembled the construction of spite fences, then we would permit blackmail and create a tort action for spiteful disclosures of embarrassing facts.

${ }^{63}$ Snme writers who stress blackmail's bad consequences pair their harm-to-society 
In combination, all the theories mentioned in this section account for many puzzles and provide ample reason to prohibit blackmail. I nonetheless find them unsatisfying for the reasons outlined above. Particularly, they do not explain very well the intuition that blackmail is often more wrong than disclosure or nondisclosure and that blackmailers wrong their victims. I believe that we can best understand the nature of blackmail's immorality by combining the accounts discussed in this section with theories of exploitation and coercion.

Patching together several accounts promises to explain and justify the condemnation and prohibition of blackmail. We should not reject partial accounts merely because they fail to explain one case or another. They might be valuable elements in a theory when paired with moral accounts that apply to other examples and with practical explanations that justify overinclusion and underinclusion. Explanations of consequential harms, even if they do not justify criminalization, often provide persuasive arguments for criminalizing acts that are immoral for other reasons.

\section{OTHER MARKET TRANSACTIONS}

Does my explanation of blackmail commit me to criminalizing other transactions? It is often lawful to negotiate with vulnerable people, and to sell things we might otherwise give away for free. If acts I define as exploitative or coercive should remain lawful, my arguments prove too much. ${ }^{64}$

claims with exploitation arguments. Jeffrie Murphy argues that blackmail creates incentives to invade privacy and that blackmailers exploit their victims. See Murphy, supra note 1, at 163-64. In this way, he explains why blackmail is a serious wrong to the victim and also provides a reason for selecting blackmail for criminal prohibition from among many potentially exploitative transactions. Lindgren criticizes Murphy's account because it cannot explain the prohibition of opportunistic blackmail. If the information is accidentally acquired, permitting the blackmail does not encourage snooping. See Lindgren, supra note 1, at 689-91. This conclusion is a hasty one. We prohibit opportunistic blackmail because there is no practical way for criminal law to distinguish entrepreneurial blackmail from opportunistic blackmail. If the law is to deter the snooping associated with the former, it must prohibit the latter as well.

64 See, e.g., Murphy, supra note 1, at 157 (noting that we do not criminalize many obviously exploitative proposals, and do permit many proposals accepted by people in circumstances more desperate than many blackmail victims). 
The arguments discussed in the prior section provide reasons to think blackmail a particularly harmful and immoral transaction, even among those that coerce and exploit. In addition, I will make two responses. First, not all hard bargaining coerces or exploits. Second, practical considerations justify permitting some coercion and exploitation. I illustrate each point in turn.

Not all hard bargaining coerces or exploits. These wrongs occur only when some item of importance is the subject of negotiation, and when there is some source of power available to one party, often monopoly. If the item is relatively unimportant or there are other providers, there will be little ability to exploit or coerce.

People with power to exploit or coerce do not always do so. Consider rescue bargains. That rescuers demand high payments for their services does not prove that they coerce or exploit. Many rescuers would not be present or would not rescue if unable to charge a fee. Unlike many blackmailers, these rescuers provide a service they would not otherwise provide. Although people in need of rescue face difficult circumstances, rescuers do not necessarily exploit these circumstances. Unless the rescuer charges a higher price for a rescue of equal difficulty when the rescuer finds that the victim faces imminent suffering or death, the rescuer has not taken advantage of the victim's hardship.

Of course, some rescue negotiations, like most blackmail negotiations, involve coercion and exploitation. Some rescuers would rescue for free if unable to bargain, and some exploit the desperate circumstances of the victim to extract promises of large payment. One might think that the principles justifying blackmail laws would also justify criminalizing some demands for payment by rescuers.

There are practical reasons, however, not to criminalize such demands. ${ }^{65}$ The rescuers who would not be present or would not perform the rescue if unable to demand payment might be difficult to differentiate from those who would rescue without payment. Unless law can sort these individuals appropriately and predictably, any criminal penalty would deter rescues. Because encouraging rescue is important, we should not risk potential deterrence by punishing those rescuers who coerce and exploit. Furthermore,

${ }^{65}$ I can think of two exceptions. Proposals to rescue for a price should be crimes when made either by public safety officials (the Coast Guard) or people who intentionally created the need of rescue in order to profit. See RESTATEMENT (SECOND) OF TORTS $\$ \$ 314-325$ (1965). 
agreements in rescue negotiations could be policed through a carefully crafted set of contractual-release doctrines.

Blackmail differs from rescue in practical terms. First, civil remedies are a less practical solution to coercion and exploitation in blackmail cases. Blackmail cannot be addressed by contract law because of the problems of monitoring promises to keep embarrassing secrets. Second, if unable to bargain, the proportion of rescuers who would rescue for free is likely to be much lower than the proportion of blackmailers who would keep the secret. Third, intentionally acquiring embarrassing information to be used for blackmail is wasteful. ${ }^{66}$ Insofar as the ban on blackmail deters people from searching for and then hiding embarrassing information, it does no harm and likely does some good. ${ }^{67}$

I do not want to overstate the difference. Criminalizing blackmail deters some individuals from purchasing silence at a price that they would be happy to pay and in contravention of no moral or legal obligation. Permitting rescuers to demand payment sometimes leads needy people to pay for rescues they might have had for free, and to pay prices inflated by their desperation. We treat the two practices differently not because there is no overlap, but because: (1) we cannot easily distinguish particular threats from particular offers; (2) we suspect that coercion and exploitation are far more common among blackmailers than among rescuers; and (3) the risk of deterring rescue is more dangerous than permitting immoral rescue bargains, while the risks of permitting coercion and exploitation in the sale of secrecy seem more serious than the harms of deterring bargains for silence. The distinctions are not those of principle. They result from the practical balancing typical in legal decisionmaking. ${ }^{68}$

${ }^{66}$ See Ginsburg, supra note 58, at 1859-65. Arguments noting that blackmail is wasteful have often been met with the claim that we do not and should criminalize wasteful bargains. Wastefulness is not a reason for banning blackmail. Rather, it is a reason for not being concerned about the effects of the ban.

67 The claim that bans on blackmail effectuate good consequences stems from several sources. First, insofar as decriminalization would encourage research blackmail, it creates an incentive for invasions of privacy. Second, insofar as contracts are difficult to enforce, decriminalization creates the potential for repeated demands for payment, and therefore may encourage criminal acts by the victim in much the way drug dependency encourages other crimes. Third, insofar as blackmail sometimes permits people to keep secrets that otherwise would have been disclosed, some important information is hidden as a result.

${ }^{68}$ Murphy asserts: 
These practical decisions can be difficult. Some transactions that regularly coerce and exploit concern items of such value that we hesitate to ban negotiations about them. Although permitting these transactions increases the coercion and exploitation of many individuals, prohibiting them would have worse consequences in those bargains that would not have been coercive.

For example, it is not usually criminal to demand payment for revealing beneficial information. Imagine that everyone wrongly believes Rich is a member of the $\mathrm{Ku} \mathrm{Klux} \mathrm{Klan}$. Bob discovers evidence showing that the rumor is false. Bob tells Rich that he will share the evidence in exchange for one million dollars. This proposal is likely to be coercive and exploitative. In this regard it resembles blackmail. But prohibiting the proposal could be problematic. Some exculpatory information is discovered intentionally and through some effort. I would hesitate to enact criminal laws that could deter discovery and disclosure of exculpatory information. In this regard, Bob's proposal is more like a rescue proposal than a typical blackmail proposal.

\section{CONCLUSION}

Although no single argument justifies condemning and prohibiting all and only blackmail transactions, overlapping arguments can accomplish this task. The most promising approach is to pair various moral objections that apply to different forms of blackmail with practical difficulties in creating exceptions for the few cases not covered. Arguments about the wastefulness of blackmail serve both as reasons not to be very concerned about overinclusive laws and as reasons for permitting transactions that seem like blackmail but are more productive.

There are several patchwork theories that might justify prohibiting blackmail, but not disclosure or hard bargains. Some of these have trouble explaining strongly held intuitions about blackmail,

We could grant that blackmail and hard economic transactions of [a certain kind] are both intrinsically immoral ... and still consistently advocate criminalization for the former but not for the latter .... We might, for example, argue that criminalizing blackmail would only deprive people of incentives it would be desirable for them not to have ... whereas criminalizing economic transactions of [this other] kind might deprive people of socially useful incentives.

Murphy, supra note 1, at 163. 
such as that it is a serious moral wrong to a victim, and that it is usually more wrong than disclosing the embarrassing information.

The seriousness of blackmail as a wrong to a victim is most easily explained if the patchwork of theories includes accounts of blackmail as coercive and exploitative. Blackmail is coercive when the blackmailer would have kept silent had the opportunity to demand payment been unavailable. Blackmail is exploitative when the blackmailer obtains a premium over other uses for her information because of the victim's hardship.

Blackmailers who neither coerce nor exploit usually breach obligations to disclose, to keep silent, or to decide on grounds other than price. Although the few blackmailers who do not coerce or exploit act in a less morally wrongful manner than those who do, creating an exception to the blackmail laws for them would be impractical. We permit other potentially coercive and exploitative transactions, such as rescue bargains, because we think coercion and exploitation are less common in these cases, and because encouraging productive exchanges is sometimes more pressing than deterring coercion and exploitation. 
